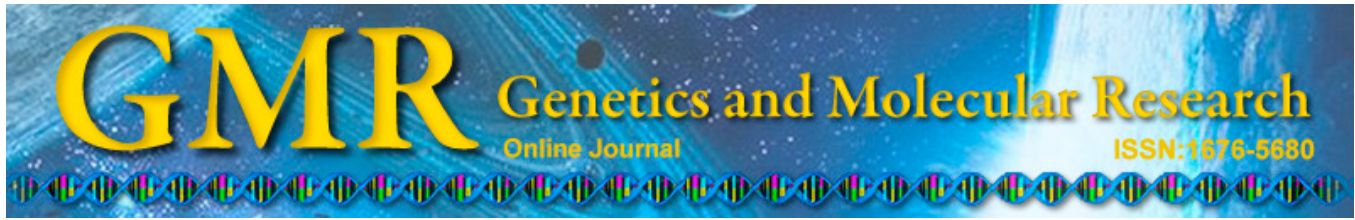

\title{
Effect of high-concentrate diet on amino acid transporter expression and milk quality in Holstein dairy cows
}

\author{
Z.L. Xie, P.S. Ye, Y.S. Zhang and X.Z. Shen \\ Key Laboratory of Animal Physiology and Biochemistry, \\ College of Veterinary Medicine, Nanjing Agricultural University, Nanjing, China \\ Corresponding author: Y.S. Zhang \\ E-mail: yuanshuzhang@njau.edu.cn
}

Genet. Mol. Res. 14 (2): 5246-5257 (2015)

Received August 7, 2014

Accepted December 10, 2014

Published May 18, 2015

DOI http://dx.doi.org/10.4238/2015.May.18.16

\begin{abstract}
In order to evaluate the effect of high-concentrate diet supplementation on milk protein content, six Holstein dairy cows were assigned into high-concentrate diet (HC) or low-concentrate diet (LC) groups ( $\mathrm{N}=3$ /group) for 50 days. With regard to milk protein, $\mathrm{HC}$ feeding significantly reduced the percentage of milk protein $(\mathrm{P}<0.01)$, and milk protein yield also reduced. The milk somatic cell count numbers and N-acetyl-D-glucosaminidase activity was significantly higher $(\mathrm{P}<$ 0.01) in the HC group than in the LC group. A pre-column derivatization procedure of o-phthalaldehyde was used to analyze the milk amino acid profile, the contents of Asp, Gln, Ala, Ile, Leu, and Lys were significantly lower in milk ( $\mathrm{P}<0.05)$, but Arg and Phe were significantly higher $(\mathrm{P}<$ $0.05)$ in the HC group than in the LC group. The mRNA abundance for amino acid transporters SLC7A8, SLC7A10 (P < 0.05), SLC1A3 $(\mathrm{P}<$ $0.05)$, and SLC16A10 $(\mathrm{P}<0.05)$ were decreased in the HC group. These data indicate that expression of amino acid transporters alters regulation of amino acid utilization and decreases milk quality in dairy cows.
\end{abstract}

Key words: High-concentrate diet; Amino acid; Amino acid transporter; Cows; Milk quality 


\section{INTRODUCTION}

Feeding practice may have an important influence on dairy cow milk production and health (Valde et al., 2007). Highly fermentable diets are used to maximize energy intake and achieve high levels of milk yield or rapid growth rates. However, highly fermentable diets also increase the rate of acid production, which causes the lipopolysaccharide increased and translocated into blood (Khafipour et al., 2009), reduced milk health (Capuco et al., 2003), somatic cell count (SCC) and N-acetyl-D-glucosaminidase (NAGase) content increased (Leitner et al., 2001). A previous study showed that alter amino acid (AA) metabolism and nitrogen balance in the plasma with increasing lipopolysaccharide content, which may be needed to compensate for the intake of protein concentration and AA metabolism demand (Waggoner et al., 2009). AAs are important for cell growth in a variety of important physiological and biochemical processes and act as a substrate involved in cellular protein synthesis. A previous study showed that amino acid transporters (AATs) played important roles in the absorption process of AAs and are important nutrient sensing molecules that play an important role in mTOR signaling pathways (Edinger, 2007). A recent study found that only a portion of the AAT was involved in regulating mTOR activation and caused mRNA translation (Heublein et al., 2010). In ruminants, a role of mTOR in the regulation of milk protein synthesis in the mammary glands has also been highlighted (Burgos et al., 2010; Toerien et al., 2010).

Milk quality regulation requires a strong interplay between all of the above elements, such as AA import/availability, AA transporter expression, NAGase, SCC, and mTOR signaling (Leitner et al., 2001; Bionaz and Loor, 2007). This element has been singularly shown to play a role in milk quality and milk protein synthesis during the onset and throughout established lactation in dairy cattle. Hence, we analyzed if high-concentrate diet changes milk metabolism and protein content during lactation.

\section{MATERIAL AND METHODS}

\section{Animals, experiment treatment, and feeding}

In this randomized complete block design study, our group used lactating Holstein dairy cows $(\mathrm{N}=6 ; 606 \pm 15 \mathrm{~kg} \mathrm{BW})$. Prior to the start of the experiment, cows were split into two blocks $(\mathrm{N}=3$ each) according to the day they were delivered, and cows in each block were randomly assigned to one of two dietary treatments. To minimize the effect of lactating stage on results, each block was enrolled in the experiment when the cows reached, on an average, the above-specified dimension. The cattle were housed in a tie-stall facility at the Nanjing Agriculture University Animal Experimental Station and procedures were approved by the Animal Care Committee of Nanjing Agriculture University. Throughout lactation, the cattle had unlimited access to fresh water and were milked twice daily in their stalls.

Before the experiment, all cattle were fed a low-concentrate diet [LC; concentrate-toforage (C:F) ratios of 4:6; Table 1] over 10 days. The high-concentrate diet (HC; C:F ratios of 6:4; Table 1) was fed in equal installments. Diets were formulated to meet or exceed the minimum nutrient requirements set by National Research Council (NRC) (2001). Using previously described methodology, dry matter intake was calculated daily for each cow during the experiment (Keunen et al., 2002). The average intake for each cow during the baseline (LC-transitional period) was fed for the remaining five periods (Pe 1, 2, 3, 4, and 5; each 10 
days/Pe). At the end of LC-transitional period, the cattle were fed an HC diet. The cattle were transitioned to the $\mathrm{HC}$ diet in equal increments over 5 days, which was fed until the end of the Pe 5 during the experiment.

Table 1. Ingredients and chemical composition of the high-concentrate (HC) diets and low-concentrate (LC) diets.

\begin{tabular}{|c|c|c|}
\hline & \multicolumn{2}{|c|}{ Diets } \\
\hline & $\mathrm{HC}$ & LC \\
\hline \multicolumn{3}{|l|}{ Ingredients (\% dry matter, DM) } \\
\hline Forage & 15.00 & 10.00 \\
\hline Lucerne & 0.00 & 25.00 \\
\hline Ensile & 25.00 & 25.00 \\
\hline Corn & 32.90 & 21.95 \\
\hline Wheat bran & 3.00 & 2.00 \\
\hline Soybean meal & 22.40 & 14.97 \\
\hline Calcium hydrogen phosphate & 0.11 & 0.08 \\
\hline Limestone & 0.60 & 0.40 \\
\hline Salt & 0.40 & 0.28 \\
\hline Premix $^{1}$ & 0.50 & 0.32 \\
\hline \multicolumn{3}{|l|}{ Chemical composition ( $\%$ of DM) } \\
\hline Net energy (NE, MJ/kg) & 6.52 & 6.32 \\
\hline Crude protein $(\mathrm{CP})$ & 17.27 & 17.24 \\
\hline Neutral detergent fiber (NDF) & 35.07 & 38.81 \\
\hline Acid detergent fiber (ADF) & 19.31 & 23.66 \\
\hline Ash & 4.71 & 6.45 \\
\hline Calcium $(\mathrm{Ca})$ & 0.44 & 0.78 \\
\hline Phosphorus (P) & 0.33 & 0.3 \\
\hline
\end{tabular}

\section{Mammary tissue, plasma, and milking}

Briefly, percutaneous biopsies from each of six cows were obtained from the right of the mammary glands. All procedures were conducted under protocols approved by the University of Nanjing Agricultural Institutional Animal Care and Use Committee.

Blood samples were collected by jugular catheter into heparinized vacutainers for $4 \mathrm{~h}$ from each cow after feeding. Blood samples were immediately placed on ice, centrifuged at $3000 \mathrm{~g}$ for $20 \mathrm{~min}$, and stored at $-20^{\circ} \mathrm{C}$ until analysis.

Individual milk yields $(\mathrm{kg})$ were recorded by milking at $04: 30$ and $17: 00 \mathrm{~h}$ daily. The milk sample was collected into a sterile tube for testing, but the first three squirts of milk were discarded. Milk protein contents were measured at the Weigang Milk Testing Laboratory (Nanjing, China) using Integrated Milk Testing ${ }^{\mathrm{TM}}$ Milkoscan 4000 (Foss Electric, Hillerod, Denmark), and the number of milk somatic cells was determined using an electronic cell counter (Fossomatic, Foss Electric, Hillerod, Denmark). The milk samples were put on ice and centrifuged twice at $3500 \mathrm{~g}$ for $30 \mathrm{~min}$ at room temperature to separate phases. Then, we collected the stratum medium, placed it into a fresh $2-\mathrm{mL}$ tube, and stored it at $-20^{\circ} \mathrm{C}$ until analysis. The treatment of high-performance liquid chromatography (HPLC) samples and methods of injection are as follows: First, milk was centrifuged at $3500 \mathrm{~g}$ at $4^{\circ} \mathrm{C}$ for $10 \mathrm{~min}$ to separate. Second, the under-layer fluid (milk-samples-new) was collected and placed in a new 2-mL tube. Third, the acetonitrile (HPLC Solvents, USA) was added into milk samples and mixed by vortexing. Fourth, the mixed samples were incubated at $4{ }^{\circ} \mathrm{C}$ for $30 \mathrm{~min}$ and centrifuged at $12000 \mathrm{~g}$ at $4^{\circ} \mathrm{C}$ for $30 \mathrm{~min}$. Fifth, the supernatant was collected and placed at $4^{\circ} \mathrm{C}$ until analysis. Sixth, $20 \mu \mathrm{L}$ 
o-phthalaldehyde was added into mixed samples and incubated for 2 min. Finally, $10 \mu \mathrm{L}$ stop buffer was added and thoroughly vortexed until analysis.

\section{AAs in milk and NAGase activity of milk and plasma}

The chromatographic conditions of the assay of amino acids in milk by HPLC were as follows: a Hypersil C18ODS column ( 4.6 x $250 \mathrm{~mm}, 5 \mu \mathrm{m}$; Waters Co., USA) was used as an analytical column. The mobile phase consisted of $80 \% 0.02 \mathrm{M} \mathrm{Na}_{2} \mathrm{HPO}_{4}-\mathrm{NaH}_{2} \mathrm{PO}_{4}$, $15 \%$ methanol (HPLC solvents), and $5 \%$ acetonitrile with $1.0 \mathrm{~mL} / \mathrm{min}$ flow rate, the detective wavelength of $340-450 \mathrm{~nm}, 20-\mu \mathrm{L}$ injection volume, and the column temperature was $40^{\circ} \mathrm{C}$. The NAGase activity in plasma and milk was determined using an NAGase kit according to manufacturer instructions. The kit was purchased from Nanjing Jiancheng Bio Institute (Nanjing, China).

\section{Real-time polymerase chain reaction (RT-PCR)}

Biopsy tissue was weighed ( 0.5-1.0 g) and immediately subjected to RNA extraction using Trizol (TaKaRa, Dalian, China) as previously described (Loor et al., 2006). RNA concentration was measured using a NanoDrop ND-1000 spectrophotometer (Desjardins and Conklin, 2011). The purity of RNA $\left(\mathrm{A}_{260} / \mathrm{A}_{280}\right)$ for all samples was above 1.85. A portion of the RNA was diluted to $1 \mu \mathrm{g} / \mu \mathrm{L}$ using DNase/RNase-free water prior to reverse transcription. The cDNA was synthesized using $2 \mu \mathrm{g}$ RNA and according to manufacturer instructions (TaKaRa). The reaction was performed in an Eppendorf Mastercycler ${ }^{\circledR}$ Gradient using the following program: the sample was heated to $95^{\circ} \mathrm{C}$ for $2 \mathrm{~min}$, kept for $5 \mathrm{~min}$ at $70^{\circ} \mathrm{C}$, and then chilled on ice. cDNA synthesis was performed for $1 \mathrm{~h}$ at $37^{\circ} \mathrm{C}$.

The qPCR was performed using $2 \mu \mathrm{L}$ cDNA combined with a mixture composed of $5 \mu \mathrm{L}$ SYBR Green Master Mix (Tiangen, China), $10-\mu \mathrm{M}$ forward and reverse primers $(0.4 \mu \mathrm{L}$ each), and $0.2 \mu \mathrm{L}$ DNase/RNase-free water in a Bio-Rad MyiQ ${ }^{\mathrm{TM}}$ Detection System (Applied Biosystems, USA). For the AAT primers (Table 2), nucleotide sequences of Bos taurus were used for primer design and searching in the European Bioinformatics Institute (http://www. ebi.ac.uk/). The reactions were performed using the following conditions: $2 \mathrm{~min}$ at $50^{\circ} \mathrm{C}, 10$ min at $95^{\circ} \mathrm{C}, 40$ cycles of $20 \mathrm{~s}$ at $94^{\circ} \mathrm{C}$ (denaturation), and $30 \mathrm{~s}$ at $60^{\circ} \mathrm{C}$ (annealing + extension), and the final extension at $72^{\circ} \mathrm{C}$ for $10 \mathrm{~min}$. Triplicate samples were used for quantitative RT-PCR. The final data were normalized using the geometric mean of the most stable genes among the ones tested as internal controls, as previously reported (Bionaz and Loor, 2007). The relative amount of mRNA for each target gene was determined from the ratio of target gene mRNA to $\beta$-actin mRNA. According to the comparative threshold cycle $(\mathrm{Ct})$ method, the amount of target mRNA normalized to $\beta$-actin and relative to an internal control was calculated by $2^{-\Delta \Delta C t}$.

\section{Statistical analysis}

Statistical analysis was conducted using ANOVA in SPSS-16.0. Differences among individual means were evaluated. The results are reported as means $\pm \mathrm{SE}$, and differences were considered significant when $\mathrm{P}<0.05$. 
Table 2. Primer sequences of targeted genes and $\beta$-actin.

\begin{tabular}{|c|c|c|c|c|}
\hline Gene & Accession No. & Primers sequence $\left(5^{\prime}-3^{\prime}\right)$ & Orientation & Product size (bp) \\
\hline$\beta$-actin & NM_173979 & $\begin{array}{l}\text { CAAGTACCCCATTGAGCACG } \\
\text { GTCATCTTCTCACGGTTGGC }\end{array}$ & $\begin{array}{l}\text { Forward } \\
\text { Reverse }\end{array}$ & 159 \\
\hline SLC7A8 & NM_001192889 & $\begin{array}{l}\text { AGAACCTTCCCAGAGCCATC } \\
\text { GGACCCATTGACTCCTCCAA }\end{array}$ & $\begin{array}{l}\text { Forward } \\
\text { Reverse }\end{array}$ & 212 \\
\hline SLC7A10 & NM_001104989 & $\begin{array}{l}\text { AAAGAACCTACCTCGTGCCA } \\
\text { GTAGCCATTGATCCCTCCGA }\end{array}$ & $\begin{array}{l}\text { Forward } \\
\text { Reverse }\end{array}$ & 214 \\
\hline SLC16A10 & NM_001192847 & $\begin{array}{l}\text { GGCAACAGACTCTCCCTCTT } \\
\text { CGATGCACATGAGAACCACC }\end{array}$ & $\begin{array}{l}\text { Forward } \\
\text { Reverse }\end{array}$ & 214 \\
\hline SLC1A3 & NM_174600 & $\begin{array}{l}\text { CATCGTGCTGACATCTGTGG } \\
\text { CCATTTCGACATCCCGGTTC }\end{array}$ & $\begin{array}{l}\text { Forward } \\
\text { Reverse }\end{array}$ & 173 \\
\hline
\end{tabular}

\section{RESULTS}

The results of dry matter intake, milk production, and milk protein during each period are shown in Table 3. The decrease in dry matter intake was significant (14.3 to $13.92 \mathrm{~kg} / \mathrm{Pe}$; $\mathrm{P}<0.01)$ in the HC group, while it was not significant in the LC group $(15.9$ to $15.58 \mathrm{~kg} / \mathrm{Pe})$. The density of the diet increased and obviously improved the milk production $(\mathrm{P}<0.01)$ during all five periods. Dietary supplementation with an HC diet significantly decreased the milk protein percentage and yield $(\mathrm{P}<0.05)$.

Table 3. Effects of feeding a high-concentrate (HC) or low-concentrate (LC) diet over time on feed intake, milk production, and milk components.

\begin{tabular}{|c|c|c|c|c|c|c|c|c|c|c|c|c|}
\hline & \multicolumn{5}{|c|}{$\mathrm{LC}$} & \multicolumn{5}{|c|}{$\mathrm{HC}$} & \multirow[t]{2}{*}{$\mathrm{SE}$} & \multirow{2}{*}{$\frac{\mathrm{P} \text { value }}{\mathrm{LC} v s \mathrm{HC}}$} \\
\hline & Pe 1 & Pe 2 & Pe 3 & $\operatorname{Pe} 4$ & Pe 5 & Pe 1 & $\operatorname{Pe} 2$ & Pe 3 & $\mathrm{Pe} 4$ & Pe 5 & & \\
\hline DMI (kg/day) & 15.90 & 15.75 & 15.75 & 15.58 & 15.62 & 14.30 & 14.01 & 13.92 & 13.98 & 13.94 & 0.069 & $<0.000$ \\
\hline Protein $(\%)$ & 2.98 & 3.13 & 3.11 & 3.21 & 3.09 & 2.60 & 2.66 & 2.63 & 2.45 & 2.51 & 0.037 & 0.000 \\
\hline Protein (kg/day) & 0.65 & 0.62 & 0.62 & 0.61 & 0.58 & 0.58 & 0.58 & 0.58 & 0.57 & 0.57 & 0.011 & 0.008 \\
\hline Milk (kg/day) & 21.92 & 19.84 & 19.91 & 18.98 & 18.74 & 22.13 & 21.99 & 22.08 & 23.43 & 22.79 & 0.590 & 0.013 \\
\hline
\end{tabular}

Data are reported as means $\pm \mathrm{SE}$ for $\mathrm{HC}$ compared with LC. Significant differences $(\mathrm{P}<0.05$ or $\mathrm{P}<0.01)$. ${ }^{3} \mathrm{Pe}=$ period.

Figure 1 displays that the SCC was significantly higher in the HC group than in the LC group $(\mathrm{P}<0.01)$. Dramatic difference in milk NAGase activity was evident between $\mathrm{HC}$ and LC cattle during the experimental period (Figure 2A). The change of milk NAGase activity was highly significant $(\mathrm{P}<0.01)$, as the NAGase concentration displayed $5.599 \pm 0.165$ and $2.051 \pm 0.346 \mathrm{U} / \mathrm{L}$, respectively. Plasma NAGase activity was higher in HC cattle than in LC cattle, but there was no significant difference $(\mathrm{P}>0.05)$ between the two groups (Figure $2 \mathrm{~B})$.

According to the AA standard, the peaks of 15 analytes in the chromatogram and their parameters were determined (Figure 3). Each standard amino acid has an independent retention time. In each amino acid, the regression coefficient was $>0.995$ over their clinical concentration ranges, and all calculated concentrations for the calibrators were within $\pm 10 \%$ of the assigned values. The different determination results showed an intraday relative standard deviation (RSD) from 2.98 to $5.63 \%$ and interday RSD from 3.69 to $5.92 \%$, and all RSDs were less than $6.00 \%$ (Table 4). Furthermore, the standard amino acid separated spectrum of a graph showed that each amino acid had independent peaks (Figure 3). The parameters overall 
showed that the experimental conditions and precision were consistent with the HPLC detection requirement.

A

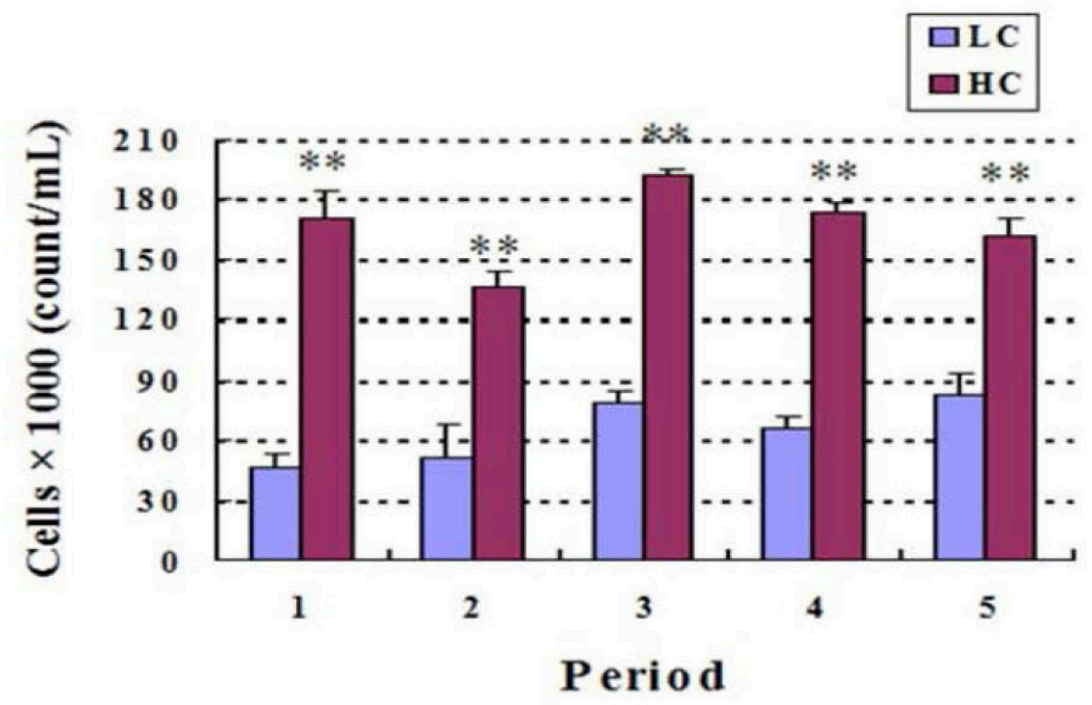

B

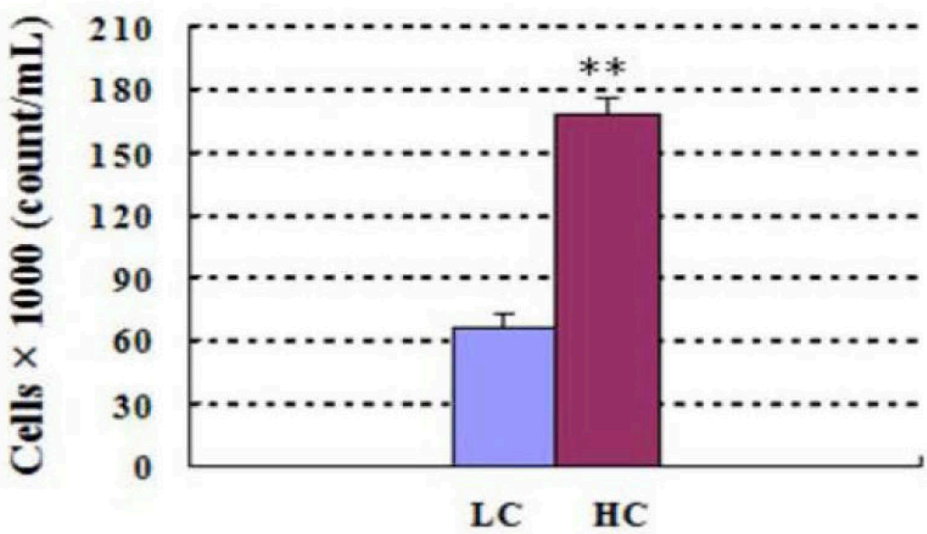

Treatment

Figure 1. Comparison of milk somatic cell number between high-concentrate (HC)- and low-concentrate (LC)feeding cattle. A. Numbers of somatic cells per period. B. Average number of somatic cells. ${ }^{* *} \mathrm{P}<0.01$. 
A

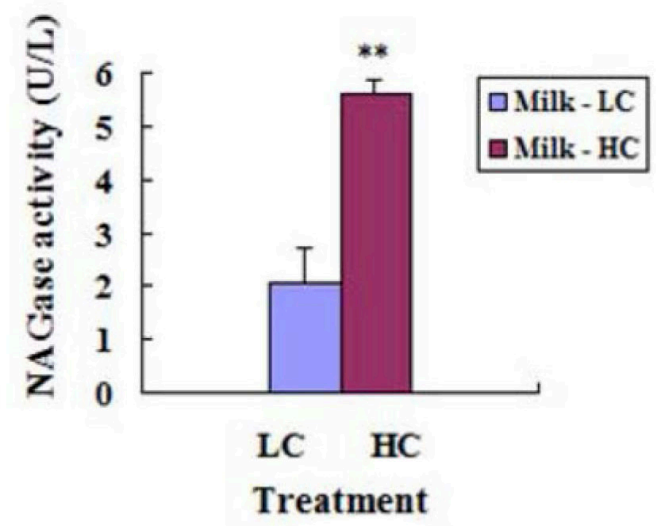

B

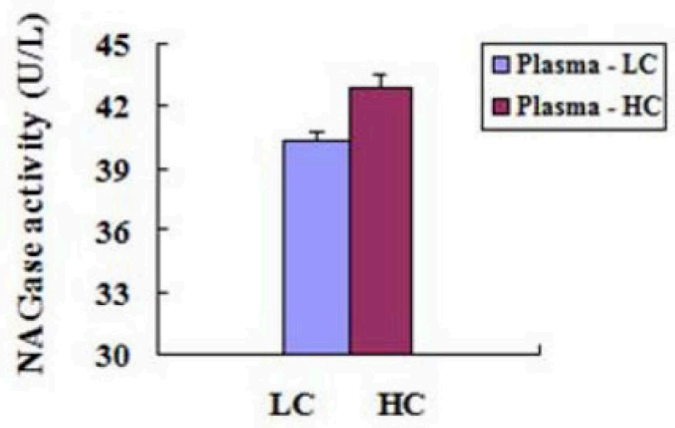

Treatment

Figure 2. NAGase activity of lactating cattle milk and plasma by colorimetric method. A. NAGase activity in milk. B. NAGase activity in plasma. $* * \mathrm{P}<0.01$

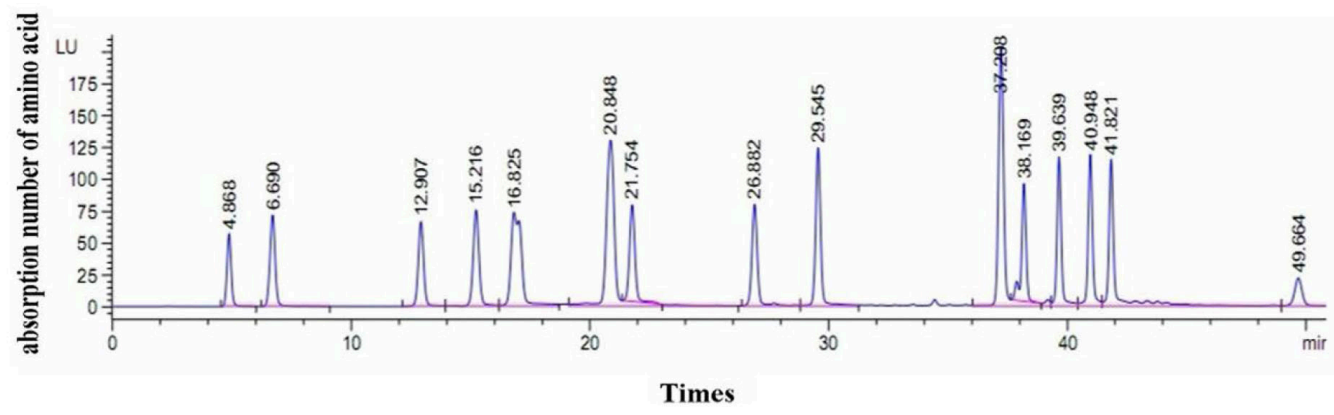

Figure 3. Synthetic mixture of 15 amino acids as shown in chromatograms. The value of each peak represents each specific amino acid, including Asp, Glu, Asn, Ser, Gln, Arg, Thr, Ala, Tyr, Val, Trp, Phe, Ile, Leu, and Lys, from left to right. 


\begin{tabular}{|c|c|c|c|c|c|}
\hline Amino acids & Retention time $(\mathrm{t} / \mathrm{min})$ & Regression equation $(\mu \mathrm{M})$ & Relation (r) & Intraday RSD & Interday RSD \\
\hline Asp & 4.868 & $y=7.7336 x+63.641$ & $r=0.996$ & 3.12 & 4.14 \\
\hline Glu & 6.690 & $y=11.611 x+85.397$ & $r=0.996$ & 3.64 & 5.01 \\
\hline Asn & 12.907 & $y=11.523 x+73.955$ & $\mathrm{r}=0.996$ & 2.98 & 3.98 \\
\hline Ser & 15.216 & $y=16.003 x+34.436$ & $r=0.996$ & 5.63 & 5.92 \\
\hline Gln & 16.825 & $y=30.476 x+2.7159$ & $\mathrm{r}=0.998$ & 3.88 & 3.97 \\
\hline Arg & 20.848 & $y=32.284 x+275.55$ & $\mathrm{r}=0.995$ & 3.62 & 4.24 \\
\hline Thr & 21.754 & $y=13.049 x+122.16$ & $r=0.996$ & 4.14 & 4.68 \\
\hline Ala & 26.882 & $y=13.471 x+99.775$ & $\mathrm{r}=0.996$ & 3.67 & 4.13 \\
\hline Tyr & 29.545 & $y=20.131 x+116.46$ & $\mathrm{r}=0.997$ & 4.54 & 5.75 \\
\hline Val & 37.208 & $y=35.549 x+123.14$ & $\mathrm{r}=0.995$ & 4.23 & 5.23 \\
\hline Trp & 38.169 & $y=16.113 x-16.951$ & $\mathrm{r}=0.999$ & 4.18 & 3.69 \\
\hline Phe & 39.639 & $y=17.072 x+21.537$ & $\mathrm{r}=0.999$ & 3.98 & 4.26 \\
\hline Ile & 40.948 & $y=18.062 x+12.063$ & $\mathrm{r}=0.996$ & 5.01 & 4.03 \\
\hline Leu & 41.821 & $y=16.530 x+37.707$ & $r=0.997$ & 4.08 & 5.33 \\
\hline Lys & 49.664 & $y=3.7118 x+26.851$ & $\mathrm{r}=0.997$ & 4.99 & 5.48 \\
\hline
\end{tabular}

$\mathrm{x}$ and $\mathrm{y}$ factors represent amino acid concentration and the area at the retention time, respectively, in the regression equation. $\mathrm{RSD}=$ relative standard deviation.

According to Table 5, in the HC group, the Asp $(\mathrm{P}<0.01)$, Gln $(\mathrm{P}<0.01)$, Ala $(\mathrm{P}<$ $0.05)$, Leu $(\mathrm{P}<0.05)$, Lys $(\mathrm{P}<0.05)$, and Ile $(\mathrm{P}<0.01)$ contents significantly decreased but the Arg $(\mathrm{P}<0.05)$ and $\mathrm{Phe}(\mathrm{P}<0.01)$ contents significantly increased. Other amino acids $(\mathrm{Glu}$, Ser, Thr, and Trp) showed no difference between HC and LC treatment $(\mathrm{P}>0.05)$. All of the measured AAs showed that the content of the aromatic AA (Phe) was increased.

Table 5. Effects of high-concentrate (HC) compared with low-concentrate (LC) diet on milk amino acid profile.

\begin{tabular}{lcr}
\hline Amino acids $(\mu \mathrm{M})$ & HC & LC \\
\hline Asp & $28.179 \pm 3.029^{* * *}$ & $63.2339 \pm 6.282$ \\
Glu & $320.837 \pm 26.191$ & $422.176 \pm 19.663$ \\
Ser & $22.585 \pm 2.239$ & $19.017 \pm 3.237$ \\
Gln & $11.286 \pm 2.968^{* *}$ & $98.537 \pm 6.890$ \\
Arg & $58.516 \pm 3.134^{*}$ & $33.077 \pm 3.205$ \\
Thr & $134.501 \pm 5.590$ & $165.400 \pm 5.574$ \\
Ala & $31.044 \pm 1.897^{*}$ & $66.958 \pm 4.193$ \\
Trp & $4.631 \pm 0.125$ & $4.184 \pm 0.552$ \\
Phe & $2.946 \pm 0.167^{* *}$ & $0.172 \pm 0.0407$ \\
Ile & $1.381 \pm 0.0523^{* *}$ & $2.669 \pm 0.0281$ \\
Leu & $1.702 \pm 0.195^{*}$ & $3.032 \pm 0.491$ \\
Lys & $10.134 \pm 0.983^{*}$ & $19.159 \pm 0.594$ \\
\hline
\end{tabular}

Data are reported as means \pm SE compared with LC cattle. $* \mathrm{P}<0.05, * * \mathrm{P}<0.01$.

The SLC7A8, SLC7A10, SLC1A3, and SLC16A10 mRNA abundances in the mammary are summarized in Figure 4. Compared with those in the LC cows, SLC7A8, SLC7A10 $(\mathrm{P}<0.05)$, SLC1A3 $(\mathrm{P}<0.05)$, and SLC16A10 $(\mathrm{P}<0.05)$ mRNA levels were lower in the HC cows.

\section{DISCUSSION}

This study analyzed the milk quality and mammary health of lactating dairy cattle during the transition from an LC to $\mathrm{HC}$ diet. To achieve this, we established a controlled feeding protocol to minimize variation in average daily feed intake, which is a common occurrence 


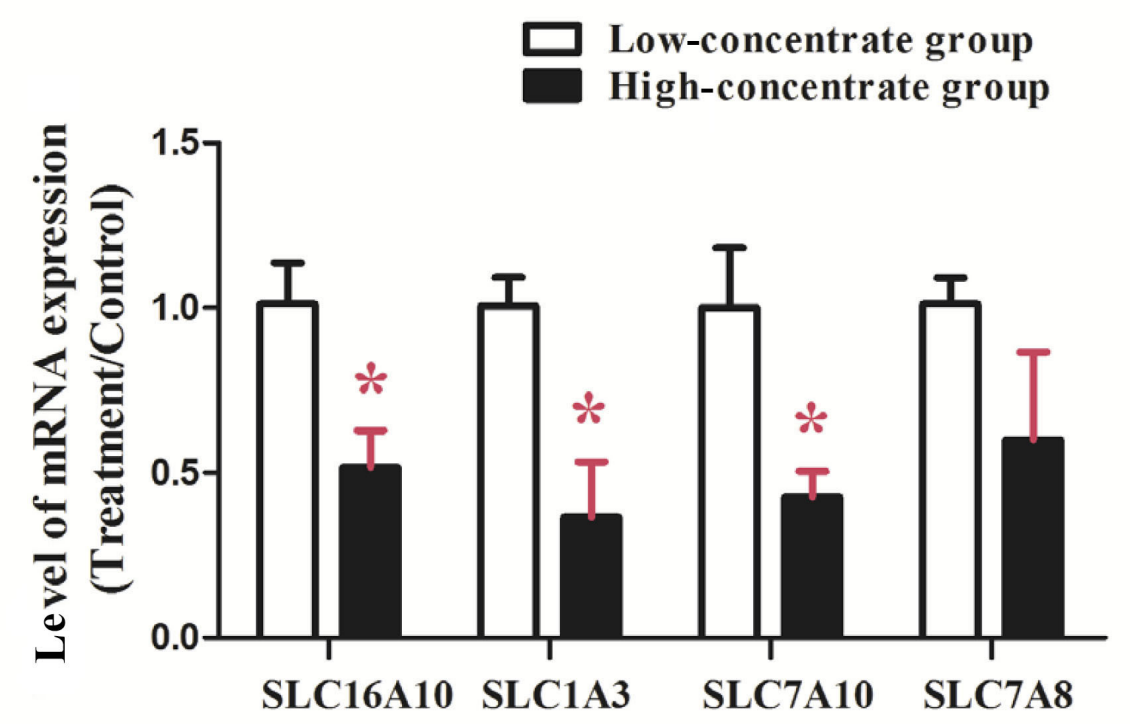

Figure 4. Expression of SLC16A10, SLC1A3, SLC7A10, and SLC7A8 genes in mammary tissue from dairy cows fed either a high-concentrate or low-concentrate diet. RNA extracted from mammary tissue was reverse transcribed to cDNA and analyzed by real-time PCR. ${ }^{*} \mathrm{P}<0.05$, difference between diets for each mRNA species.

in cattle that are rapidly fed a fermentable diet ad libitum (Penner et al., 2009). NAGase is an acidic hydrolase that is located within the lysosome and is secreted while the body is damaged, stressed, or diseased (Kitchen and Masters, 1985). In ruminants, it has been confirmed that milk NAGase activity significantly increased and was attributed to mammary epithelial cells that were damaged in mastitis (Leitner et al., 2001). Therefore, NAGase can reflect the destructiveness of sensitiveness index in mammary epithelial cells. In the healthy mammary gland $(<105$ somatic cells $/ \mathrm{mL}$ milk), most viable somatic cells are macrophages and lymphocytes (Kehrli Jr. and Shuster, 1994), but a few are neutrophils and epithelial cells (Rodrigues et al., 2009). In the present study, the results showed that feeding an HC diet significantly increases the SCC content and NAGase activity, but the milk protein percentage and yield were obviously decreased. Previous studies showed that milk protein has a negative correlation with SCC (Burriel, 1997). Thus, our group assumed that milk quality decreased with HC diet supplementation.

Milk protein is also an important index of milk quality. Thus, AA availability in bovine mammary glands is the primary limiting factor of milk protein synthesis, and it reduces milk quality (Bequette et al., 1998). In vivo, AA is not only the raw materials of protein synthesis, but also metabolism in energy supplementation. In particular, glycogenic amino acids can be transformed to glucose, of which the main sources are albuminolysis and utilization of $\alpha$-keto acid synthesis in organisms and plays an important role in participating energy metabolism (Battezzati and Riso, 2002). Recent studies have found that AAs have an important role as signaling molecules that regulate eukaryotic initiation factor phosphorylation (Wang and Proud, 2008), thereby regulating mRNA translation initiation phase and protein synthesis (Kobayashi et al., 2003). Our results describe AA changes of 12 amino acids in milk that were 
unambiguously and accurately separated according to the eluting peaks time of standard AA (Figure 3 and Table 5). According to Table 5, glycogenic amino acid decreased, indicating that the cows do not have enough AA to use in the milk protein synthesis in the HC group. This is consistent with the findings of a previous study (Brasse-Lagnel et al., 2009).

Most AAs can be effectively degraded or broken down in the liver, with the exception of branched-chain AAs (BCAAs). This means that basic BCAA are not directly metabolized by the liver. When the body needs AAs as an energy source, the efficiency of BCAA when oxidized to ATP is obviously higher than the other AAs (Rennie et al., 2006), and then reduced AA availability inhibits protein synthesis in the muscle tissue (Kobayashi et al., 2003). A similar study found that the reduction in blood BCAA may be associated with blood sugar regulation improvement (Laferrere et al., 2011). Our results show that SLC7A8 and SLC7A10 were down-regulated in the HC group. Interestingly, SLC7A8 and SLC7A10 code for AAT systems L and ASC that specifically import neutral AAs, including BCAAs (Leu and Ile) (Fuchs and Bode, 2005).

Alternatively, the BCAA contents, including Leu and Ile, were remarkably lower in this study. These data showed that the plasma BCAA may decrease the availability of circulation for milk protein synthesis in mammary glands. The decrease in expression of those transporters indicates an inactive import into BCAAs and several other essential AAs. Importantly, BCAA, as a signal molecule, plays an important role in regulatory milk protein synthesis in bovine mammary glands (Kimball and Jefferson, 2006; Sancak and Sabatini, 2009). Leu activation of the mTOR pathway appears to take place via multiple mechanisms, including direct activation of mTOR by amino acid medium vps34 (MacKenzie et al., 2009), which increases the assembly of the eiF4F complex (Kimball and Jefferson, 2006) and has a stimulatory effect on the phosphorylation status of eiF4G and p70S6K with regard to inducing protein synthesis (Huang et al., 2009). This result is consistent with previous data that showed that those AAs are lacking in the bovine mammary gland. As a result, protein synthesis was inhibited (Sancak and Sabatini, 2009; Burgos et al., 2010; Toerien et al., 2010).

Surprisingly, SLC1A3 expression, which encodes the EAAT3 that transports Glu and Arg and is among the non-essential AAs, was down-regulated in the HC group. Glu is the most abundant AA in milk and also has one of the greatest rates of import into mammary gland (Shennan, 1998). However, the SLC1A3 was down-regulated and decreased Glu content in the milk (Table 5). As discussed above, the reason for this reduction in milk protein may be down-regulation of the expression of those AATs.

In conclusion, this study explored feeding cattle an $\mathrm{HC}$ diet, which resulted in increased milk production but decreased percentage of milk protein. Meanwhile, milk SCC content and NAGase activity increased. Bovine milk protein synthesis is decreased by decreasing AAT transport of AAs into mammary epithelium, with decreases of intramammary Leu and a consequent reduction of mTOR signaling or general translation. The differential changes of AA offer new insights into milk protein synthesis with high concentrate diet supplementation. Enhancing our knowledge of the effects on milk quality to feed an HC diet may help develop novel feeding strategies to mitigate the detrimental effects of the availability of circulating BCAA and improve milk quality.

\section{ACKNOWLEDGMENTS}

Research supported by the National "973" Project on Milk Composition Precursors, Redistribution Mechanism, and Epigenetic Mechanism in the Liver (\#2011CB100802) and the 
Priority Academic Program Development of Jiangsu Higher Education Institutions (PAPD). We are grateful to Dr. M. Malhi for reading the manuscript.

\section{REFERENCES}

Battezzati A and Riso P (2002). Amino acids: fuel, building blocks for proteins, and signals. Nutrition 18: 773-774.

Bequette BJ, Backwell FR and Crompton LA (1998). Current concepts of amino acid and protein metabolism in the mammary gland of the lactating ruminant. J. Dairy Sci. 81: 2540-2559.

Bionaz M and Loor JJ (2007). Identification of reference genes for quantitative real-time PCR in the bovine mammary gland during the lactation cycle. Physiol. Genomics 29: 312-319.

Brasse-Lagnel C, Lavoinne A and Husson A (2009). Control of mammalian gene expression by amino acids, especially glutamine. FEBS J. 276: 1826-1844.

Burgos SA, Dai M and Cant JP (2010). Nutrient availability and lactogenic hormones regulate mammary protein synthesis through the mammalian target of rapamycin signaling pathway. J. Dairy Sci. 93: 153-161.

Burriel AR (1997). Dynamics of intramammary infection in the sheep caused by coagulase-negative staphylococci and its influence on udder tissue and milk composition. Vet. Rec. 140: 419-423.

Capuco AV, Ellis SE, Hale SA and Long E (2003). Lactation persistency: insights from mammary cell proliferation studies. J. Anim. Sci. 81 (Suppl 3): 18-31.

Desjardins PR and Conklin DS (2011). Microvolume quantitation of nucleic acids. In: Current protocols in molecular biology (Ausubel FM, et al., eds.). Appendix 3: 3J.

Edinger AL (2007). Controlling cell growth and survival through regulated nutrient transporter expression. Biochem. J. 406: 1-12.

Fuchs BC and Bode BP (2005). Amino acid transporters ASCT2 and LAT1 in cancer: partners in crime? Semin. Cancer Biol. 15: 254-266.

Heublein S, Kazi S, Ogmundsdóttir MH, Attwood EV, et al. (2010). Proton-assisted amino-acid transporters are conserved regulators of proliferation and amino-acid-dependent mTORC1 activation. Oncogene 29: 4068-4079.

Huang BP, Wang Y, Wang X, Wang Z, et al. (2009). Blocking eukaryotic initiation factor 4F complex formation does not inhibit the mTORC1-dependent activation of protein synthesis in cardiomyocytes. Am. J. Physiol. Heart Circ. Physiol. 296: H505-514.

Kehrli ME Jr and Shuster DE (1994). Factors affecting milk somatic cells and their role in health of the bovine mammary gland. J. Dairy Sci. 77: 619-627.

Keunen JE, Plaizier JC, Kyriazakis L, Duffield TF, et al. (2002). Effects of a subacute ruminal acidosis model on the diet selection of dairy cows. J. Dairy Sci. 85: 3304-3313.

Khafipour E, Krause DO and Plaizier JC (2009). A grain-based subacute ruminal acidosis challenge causes translocation of lipopolysaccharide and triggers inflammation. J. Dairy Sci. 92: 1060-1070.

Kimball SR and Jefferson LS (2006). New functions for amino acids: effects on gene transcription and translation. Am. J. Clin. Nutr. 83: 500S-507S.

Kitchen BJ and Masters CJ (1985). Purification and properties of bovine mammary gland N-acetyl-beta-D-glucosaminidase. Biochim. Biophys. Acta 831: 125-132.

Kobayashi H, Børsheim E, Anthony TG, Traber DL, et al. (2003). Reduced amino acid availability inhibits muscle protein synthesis and decreases activity of initiation factor eIF2B. Am. J. Physiol. Endocrinol. Metab. 284: E488-E498.

Laferrere B, Reilly D, Arias S, Swerdlow N, et al. (2011). Differential metabolic impact of gastric bypass surgery versus dietary intervention in obese diabetic subjects despite identical weight loss. Sci. Transl. Med. 3: 80re82.

Leitner G, Chaffer M, Zamir S, Mor T, et al. (2001). Udder disease etiology, milk somatic cell counts and NAGase activity in Israeli Assaf sheep throughout lactation. Small Rumin. Res. 39: 107-112.

Loor JJ, Dann HM, Guretzky NA, Everts RE, et al. (2006). Plane of nutrition prepartum alters hepatic gene expression and function in dairy cows as assessed by longitudinal transcript and metabolic profiling. Physiol. Genomics 27: 29-41.

MacKenzie MG, Hamilton DL, Murray JT, Taylor PM, et al. (2009). mVps34 is activated following high-resistance contractions. J. Physiol. 587: 253-260.

Penner GB, Taniguchi M, Guan LL, Beauchemin KA, et al. (2009). Effect of dietary forage to concentrate ratio on volatile fatty acid absorption and the expression of genes related to volatile fatty acid absorption and metabolism in ruminal tissue. J. Dairy Sci. 92: 2767-2781.

Rennie MJ, Bohe J, Smith K, Wackerhage H, et al. (2006). Branched-chain amino acids as fuels and anabolic signals in human muscle. J. Nutr. 136: 264S-268S.

Rodrigues AC, Cassoli LD, Machado PF and Ruegg PL (2009). Short communication: evaluation of an on-farm test to 
estimate somatic cell count. J. Dairy Sci. 92: 990-995.

Sancak Y and Sabatini DM (2009). Rag proteins regulate amino-acid-induced mTORC1 signalling. Biochem. Soc. Trans. 37: $289-290$.

Shennan DB (1998). Mammary gland membrane transport systems. J. Mammary Gland Biol. Neoplasia 3: 247-258.

Toerien CA, Trout DR and Cant JP (2010). Nutritional stimulation of milk protein yield of cows is associated with changes in phosphorylation of mammary eukaryotic initiation factor 2 and ribosomal s6 kinase 1. J. Nutr. 140: 285-292.

Valde JP, Lystad ML, Simensen E and Osteras O (2007). Comparison of feeding management and body condition of dairy cows in herds with low and high mastitis rates. J. Dairy Sci. 90: 4317-4324.

Waggoner JW, Loest CA, Turner JL, Mathis CP, et al. (2009). Effects of dietary protein and bacterial lipopolysaccharide infusion on nitrogen metabolism and hormonal responses of growing beef steers. J. Anim. Sci. 87: 3656-3668.

Wang X and Proud CG (2008). A novel mechanism for the control of translation initiation by amino acids, mediated by phosphorylation of eukaryotic initiation factor 2B. Mol. Cell. Biol. 28: 1429-1442. 